\title{
[odczytania]
}

\section{Katarzyna Warska: Dzieciństwo w biografii pisarza. Przypadek Brunona Schulza}

Tradycyjny model całościowej biografii pisarza zakłada, że autor podejmie próbę opowiedzenia życia bohatera od narodzin do śmierci - zazwyczaj $\mathrm{z}$ odtworzeniem historii rodowej, a nieraz też z dziejami pośmiertnymi ciała lub przywołaniem aktów pamięci po zmarłym ${ }^{1}$. W tym modelu biograf stara się odsłonić przed czytelnikiem wszystkie fazy życia bohatera. dwa modele biografii Model selektywny, reprezentowany przez wszelkiego rodzaju biografie tematyczne, przewiduje zaś dobór wydarzeń ze względu na wybrany aspekt ludzkiej egzystencji albo koncentruje się na danej fazie życia bohatera. (Oba te modele mogą występować $\mathrm{w}$ wariancie chronologicznym lub zakładającym inny porządek prezentacji wydarzeń, na przykład z perspektywy kluczowego momentu życia, który zostaje opowiedziany na początku, lub w porządku tematycznym, na przykład miejsc lub osób).

Takie książki jak Regiony wielkiej herezji Jerzego Ficowskiego, Schulz pod kluczem Wiesława Budzyńskiego, Bruno. Epoka genialna Anny Kaszuby-Dębskiej, a w jakimś sensie także należące do gatunku biograficznego dwa teksty Jerzego Jarzębskiego: Schulz z serii „A to Polska właśnie” i wstęp do wydania w serii „Biblioteka Narodowa”, są z założenia

1 Ciągłość między biografią a nekrografią potwierdzają choćby słowa Janusza Sławińskiego: „Śmierć wybitnej osoby (wiemy to od Gundolfa) nie jest bynajmniej kresem dziania się jej biografii" (J. Sławiński, Czas wspomnień, w: Wspomnienia o Julianie Przybosiu, oprac. i wstępem poprzedził J. Sławiński, Warszawa 1976, s. 7). 
próby scalenia

biografie selektywne całościowe ${ }^{2}$. Przyświecał im cel ogarnięcia wszystkiego, co do tej pory znane (Ficowski, Jarzębski, Kaszuba-Dębska), albo uzupełnienia dotychczasowego stanu wiedzy o nowe elementy (Budzyński), zasadniczo pochodzące ze wszystkich faz i obszarów życia, a więc niepoddawane selekcji tematycznej. Jak trudne stało przed autorami tych biografii zadanie, wyjaśnia Jarzębski: „Bruno Schulz nie był pisarzem, o którym łatwo byłoby napisać książkę skomponowaną według modelu «życie i twórczość». To, co o jego życiu wiemy, nie nadaje się na romantyczną fabułę. [...] Biografia Schulza zaiste nie jest tematem na dłuższą narrację"3. W związku z tym Jarzębski docenia działania Ficowskiego: „Czytelnikowi urodzonemu blisko końca naszego wieku niełatwo czasami z dzisiejszej perspektywy zrozumieć, dlaczego biografia Schulza wymagała tak żmudnych zabiegów rekonstruktorskich, którym Jerzy Ficowski, naczelny znawca schulzowskiej problematyki, nieledwie życie poświęcił. W rzeczywistości te badania dlatego były tak trudne, że naturalne środowisko pisarza, środowisko galicyjskich Żydów, zostało przez wojnę przetrzebione nieomal do zaniku"4.

Selektywny model biografii na pierwszy rzut oka wydaje się mniejszym wyzwaniem. Przeczą temu jednak dwie tematyczne biografie Andrzejewskiego autorstwa Anny Synoradzkiej-Demadre: Andrzejewski i Jerzy Andrzejewski. Przyczynek do biografii prywatnej ${ }^{5}$. Trudno je nazwać skromnymi i niewątpliwie stoi za nimi tytaniczna praca. Od modelu selektywnego zaczęła Kaszuba-Dębska, publikując najpierw Kobiety i Schulza ${ }^{6}$. $\mathrm{W}$ tym herstory w dużym stopniu chodzi też o Schulza, tyle że jego życie zostaje opowiedziane z perspektywy relacji z kobietami (co wcześniej uczynił Jarzębski w podrozdziale „Kobiety” w popularnonaukowym Schulzu). Podobną drogę pokonała Klementyna Suchanow, która najpierw przygotowała Argentyńskie przygody Gombrowicza, a następnie całościową biografię zatytułowaną Gombrowicz. Ja, geniusz ${ }^{7}$. Od ogółu do szczegółu zaś przeszedł Budzyński. Pod model selektywny mogliby podlegać $U c z-$ niowie Schulza, w których patrzy na losy pisarza przez pryzmat relacji jego byłych podopiecznych. Przy okazji, podobnie jak Kaszuba-Dębska,

2 Zob. J. Ficowski, Regiony wielkiej herezji i okolice, Sejny 2002; W. Budzyński, Schulz pod kluczem, Warszawa 2001; A. Kaszuba-Dębska, Bruno. Epoka genialna, Kraków 2020; J. Jarzębski, Wstęp, w: B. Schulz, Opowiadania. Wybór esejów i listów, oprac. J. Jarzębski, wyd. 2 przejrzane i uzupełnione, Wrocław 1998 (BN I 264); idem, Schulz, Wrocław 1999. J. Jarzębski, Schulz, Wrocław 1999, s. 6.

4 Ibidem, s. 39.

5 A. Synoradzka-Demadre, Andrzejewski, Kraków 1997; eadem, Jerzy Andrzejewski. Przyczynek do biografii prywatnej, Warszawa 2016.

6 A. Kaszuba-Dębska, Kobiety i Schulz, Gdańsk 2016.

7 K. Suchanow, Argentyńskie przygody Gombrowicza, Kraków 2005; eadem, Gombrowicz. Ja, geniusz, t. 1, Wołowiec 2017. 
opowiada inną historię - uczniów, którzy są jego rozmówcami, i innych mieszkańców Drohobycza, w ten czy inny sposób wplecionych w rozległa sieć relacji z Schulzem ${ }^{\mathbf{8}}$. Jeszcze bardziej Budzyński oddala się od Schulza we - wcześniejszym niż Uczniowie - Mieście Schulza 9 .

Niezależnie od wyboru modelu biografii Schulza za próbą jej napisania stoją zasadniczo dwie motywacje. Pierwsza to ukazanie tak zwanej prawdy o bohaterze, jego życiu i otoczeniu. Istnienie tej motywacji potwier-

pierwsza motywacja biografa

przyczyny nieistnienia prawdy

8 W. Budzyński, Uczniowie Schulza, Warszawa 2011.

9 Idem, Miasto Schulza, Warszawa 2005.

10 A. Kaszuba-Dębska, Bruno. Epoka genialna, Kraków 2020, s. 9. W wywiadzie przeprowadzonym przez Polinę Justovą Kaszuba-Dębska wyjaśnia powody, dla których podjęła się pisania biografii: „Ale przede wszystkim brakowało mi całościowej biografii, której dominantą byłaby prawda, może bolesna, ale prawda, a nie mityczna poetycka opowieść" (https://culture.pl/pl/artykul/annakaszuba-debska-schulz-czytany-na-nowo-wywiad-0; dostęp: 24.01.2021).

11 Zob. M.P. Markowski, Pragnienie obecności. Filozofie reprezentacji od Platona do Kartezjusza, Gdańsk 1999; idem, O reprezentacji, w: Kulturowa teoria literatury. Główne pojęcia i problemy badawcze, red. M.P. Markowski, R. Nycz, wyd. 2, Kraków 2012, s. 287-333.

12 Zob. H. White, Zdarzenie historyczne, przeł. R. Borysławski, w: idem, Proza historyczna, pod red. E. Domańskiej, Kraków 2009, s. 251 i nast. 
poetyckimi przedstawieniami prawdopodobnych wersji przeszłości"13. Odwołanie do poezji jest może tym bardziej celne niż do powieści, że za pomocą słów biograf konstruuje własną wersję opowieści o bohaterze, w której pisze tyleż o tym, o kim pierwotnie zamierzał, co o sobie samym - niepodobna bowiem uniknąć elementów autobiografii w biografii. Stanisław Rosiek określa to jako banalną prawdę, pisząc tym razem nie o badaniach nad Schulzem, lecz nad Mickiewiczem, „że studiowanie czyjejś biografii - zwłaszcza biografii wielkiej - rzadko bywa bezinteresowne, że biograf wnosi siebie samego, swoje horyzonty, swoją moralność. I wedle niej kroi wizerunek swego bohatera"14.

Nie ma biografii, która nie osuwałaby się w inny gatunek, nie nosiła znamion dodatkowej konwencji literackiej. White - rozwijając model Northropa Frye’a - wyznaczył cztery wzorce fabularne pisarstwa historycznego: tragedię, komedię, satyrę i romans ${ }^{15}$. Schulzologowie, analizując biografie autora Sklepów cynamonowych, szukają szczegółowszych odpowiedzi. Na przykład Jakub Orzeszek dostrzega w tekstach Ficowskiego efekt żałoby po zmarłym Schulzu ${ }^{16}$. Tak rozpatrywane Regiony wielkiej herezji są tyle biografią, ile elegią. Jerzy Kandziora pamięta, by w kontekście Ficowskiego „przywołać tradycję wielkiej powieści realistycznej, której autor Regionów wielkiej herezji był admiratorem"17. Marcin Romanowski natomiast uznaje Schulza pod kluczem Budzyńskiego za biografię reportażową, która stawia pamięć ponad historią ${ }^{\mathbf{1 8}}$.

Wydaje się jednak, że jakaś - choćby bardzo cienka - nić łączy „realne" wydarzenia z opowieścią biografa - niechby to była tylko jego dobra wola. Philippe Lejeune zapewnia: „Bez wątpienia prawda jest nieosiągalna, szczególnie gdy dotyczy życia ludzkiego, ale pragnienie jej zdobycia określa pole dyskursu i aktów poznawczych, pewien typ relacji ludzkich, bynajmniej nie iluzorycznych"19. Biografowi pozostaje zatem do spełnienia wyrażona przez Paula Ricœura potrzeba snucia narracji. Mimo że prawda wciąż i wciąż wymyka się opowiadającemu, nieobojętna etycznie narracja pozostaje ważnym narzędziem (czy raczej działaniem), za

13 H. White, Tekst historiograficzny jako artefakt literacki, przeł. M. Wilczyński, w: idem, Poetyka pisarstwa historycznego, pod red. E. Domańskiej i M. Wilczyńskiego, Kraków 2000, s. 105.

14 S. Rosiek, Mickiewicz (po śmierci). Studia i szkice nekrograficzne, Gdańsk 2013, s. 10.

15 H. White, Tekst historiograficzny jako artefakt literacki, s. 68-87. Zob. też: N. Frye, Anatomia krytyki, przeł. M. Bokiniec, Gdańsk 2012.

16 J. Orzeszek, Schulz i żałoba. O drugim ciele pisarza, "Schulz/Forum” 14, 2019, s. 168-185.

17 J. Kandziora, Jerzy Ficowski o Schulzu - między rekonstrukcjq a retorykq. (Refleksje nad „Regionami wielkiej herezji)", ,Schulz/Forum" 3, 2013, s. 58.

18 M. Romanowski, Biografia reportażowa w epoce upamiętnienia. OSchulzu pod kluczem" Wiesława Budzyńskiego, "Jednak Książki. Gdańskie czasopismo humanistyczne” 2016, nr 5, s. 42.

19 P. Lejeune, Czy można zdefiniować autobiografię?, przeł. R. Lubas-Bartoszyńska, w: idem, Wariacje na temat pewnego paktu. O autobiografii, Kraków 2007, s. 5. 
pomocą którego moglibyśmy poznawać siebie innego i innego drugiego - tego-który-jest-sobą ${ }^{20}$. Tą nieesencjalną drogą stara się podążać na przykład Hanna Kirchner: „Czy ten dystans pozwala mi dotrzeć do Nałkowskiej «prawdziwej», pozbawionej masek i kostiumów, odartej z zasłon samozłudy? Założenie jest nieprawidłowe. Bieg życia pisarki, zapis jej doświadczenia wewnętrznego potwierdzają wiedzę o człowieku, jakiej dopracowała się w swoim dziele, i jej ona także dotyczy. To właśnie próbuję w tej książce uwidocznić - że "prawdziwy» jest człowiek w c a ł o ś c i swoich najbardziej nawet sprzecznych pierwiastków. Günter Grass nie bez przyczyny sięgnął w swojej autobiografii po metaforę obierania cebuli. Ona bowiem jest tylko jednością warstw, do ostatniego płatka"21.

Przyjmijmy zatem, że wartością jest sama próba docierania do prawdy, a także - zgadzając się tym samym z Frankiem Ankersmitem - że mimo wszystko były jakieś zdarzenia, do których poznania - mimo wiedzy o nieuchronności swej klęski - nieustannie i wytrwale dąży badacz przeszłości, którym jest autor biografii 22. Prawdą w biografii nie nazwiemy wtedy tego, co się wydarzyło. Będzie nią prawda obrazu, jak w metaforze Ankersmita, który widzi historyka jako artystę malarza oddającego ogólny klimat sceny ${ }^{23}$.

Przyjęcie choćby słabej, Ankersmitowskiej definicji prawdy zdaje się bynajmniej nie zwalniać biografa ze zobowiązań, które ma względem swego bohatera, a w każdym razie - jak to stwierdziłam wyżej - sami biografowie czują ten ciężar na swoich barkach. Reprezentacja mimo zastępowania oryginału dąży, by mu dorównać ${ }^{\mathbf{2 4}}$. Decyzje biografa dotyczące doboru materiału i sposobów jego prezentacji nie pozostają bez moralnych konsekwencji. Jak to aforystycznie ujął Ricœur - „nie ma opowieści obojętnej etycznie"25. W wypadku biografii komplikacje etyczne mają dodatkowy wymiar. Biograf bowiem podpisuje pakt moralny, nazwijmy go zgodnie z tradycją paktem biograficznym, który chroni czytelnika dającego wiarę w opowieść i przyjmującego zasady narzucane przez autora i tekst. Bez tej umowy odbiorca stałby na z góry przegranej pozycji26.

20 P. Ricœur, O sobie samym jako innym, przeł. B. Chełstowski, naukowo oprac. i wstępem poprzedziła M. Kowalska, Warszawa 2018, zwłaszcza "Badanie VI. Ten-który-jest-sobą i tożsamość narracyjna”.

21 H. Kirchner, Nałkowska albo życie pisane, wyd. 2, Warszawa 2011, s. 9. Podkreślenie - H. K.

22 Zob. F. Ankersmit, Sześć tez o narratywistycznej filozofii historii, przeł. E. Domańska, w: idem, Narracja, reprezentacja, doświadczenie. Studia z teorii historiografii, pod red. i ze wstępem E. Domańskiej, Kraków 2004.

23 F. Ankersmit, Zwrot lingwistyczny: teoria literatury a teoria historii, w: idem, Narracja, reprezentacja, doświadczenie, s. 88 i nast.

24 Zob. F. Ankersmit, Pochwała subiektywności, „Er(r)go. Teoria - Literatura - Kultura” 2001, nr 2 (3), s. 21.

25 P. Ricœur, O sobie samym jako innym, s. 191-192.

26 Termin "pakt biograficzny”, niejednokrotnie wykorzystywany w badaniach biograficznych, został oczywiście ukuty na zasadzie analogii do paktu autobiograficznego Philippe'a Lejeune'a. 
zdarzenia apelują

nieuchronna selekcja
Przeanalizowaliśmy aspekt jakościowy relacji między życiem a biografią, pozostaje nam zatem do omówienia relacja ilościowa. Narodziny i śmierć wyznaczają początek i koniec osi czasu, na której można oznaczyć policzalną i uchwytną liczbę punktów (zdarzeń) i zakresów (okresów, faz życia). Na mocy zobowiązania wobec bohatera i czytelnika zdarzenia oznaczone na tej osi w nieokreślony sposób apelują do biografa o reprezentację w jego opowieści. To, co się wydarzyło, powinno zostać opowiedziane. Plan opowieści i plan życia powinny być zbieżne. Oczywiście i tej powinności nie da się wypełnić - jest to technicznie niemożliwe, ale też strategicznie niepotrzebne. Nie wszystko nas (zarówno biografów, jak i czytelników) bowiem interesuje. W tym sensie każda biografia całościowa ma wymiar selektywny, jest cząstką, wycinkiem, epizodem. Michał Paweł Markowski pisał na ten temat dla „Tygodnika Powszechnego": "Jako narracja na temat życia, biografia jest sztuką wykluczeń, wyborów i pominięć"27.

Biograf celowo skupia uwagę odbiorcy na różnych wydarzeniach. Najpierw dobiera te, o których w ogóle zamierza opowiedzieć, następnie ustawia je w odpowiedniej kolejności w toku narracji. Na przykład Kaszuba-Dębska zaczyna Brunona. Epokę genialną od próby rekonstrukcji wyjazdu Schulza do Paryża. Budzyński powraca do śmierci, a Jarzębski do narodzin Schulza ${ }^{28}$. Więcej i dłużej biograf opowiada o tych zdarzeniach, które z jakiegoś powodu uważa za szczególne. Chciał tego już amerykański historyk Paul Murray Kendall, którego słowa następująco referuje Anita Całek: „autor [biografii] winien przeznaczać więcej miejsca na określone wydarzenia nie w zależności od ilości posiadanego materiału, lecz uwzględniając wagę konkretnego faktu w życiu portretowanej postaci"29.

Dobierając ważne wydarzenia, autor może iść za głosem intuicji, zawierzać wyznaniu samego bohatera, który uważał jakieś wydarzenie za ważące na jego życiu, opierać się na tradycji w badaniach nad danym bohaterem, przestrzegać hierarchii swoich czasów i/lub obowiązującej konwencji pisania biografii. Sylwia Chwedorczuk kieruje się współczesną,

27 M.P. Markowski, Cień biografa. Życie odkrywane, „Tygodnik Powszechny” 2010, nr 17, dod., także online: https://www.tygodnikpowszechny.pl/cien-biografa-145068 (dostęp: 24.01.2021).

28 W. Budzyński, Schulz pod kluczem, rozdz. "Krwawy czwartek” oraz „Zawiadowca gabinetu rysunkowego"; J. Jarzębski, Schulz, s. 7 i $28 .$.

29 A. Całek, Biografia naukowa: od koncepcji do narracji. Interdyscyplinarność, teorie, metody badawcze, Kraków 2013, s. 30. 
mającą pobudki etyczne potrzebą odsłaniania wcześniej tabuizowanej relacji homoseksualnej między Anną Kowalską a Marią Dąbrowską (przez co - nawiasem mówiąc - odtwarza w narracji swojej biografii dominację Dąbrowskiej nad Kowalską; szczęśliwie patrzy na życie poetki przez pryzmat innej kobiety, gdyby zaś ogłosiła jako biografię książkę $\mathrm{w}$ istocie poświęconą relacji kobiety z bardziej wpływowym mężczyzną, pewnie poważnie naraziłaby się liberalnej krytyce) ${ }^{\mathbf{3 0}}$. Proces wytoczony przez spadkobierców Ryszarda Kapuścińskiego ściągnął na siebie Artur Domosławski, który przedstawił wydarzenia z życia reportera, stawiając pytanie o granicę prywatnego i publicznego, etycznego i nieetycznego, co prawdopodobnie okazało się aktem założycielskim dla nowoczesnej polskiej biografistyki ${ }^{31}$. Motywacje biografa mogą być zupełnie indywidualne, jak w wypadku Synoradzkiej, która włączyła do biografii prywatnej Andrzejewskiego rozdział rozsadzający jej konstrukcję, by naprawić swój błąd z poprzedniej książki ${ }^{32}$. Tradycyjnie w biografiach Schulza najważniejsza wydaje się jego śmierć: założycielska dla Regionów wielkiej herezji, rozpoczynająca Schulza pod kluczem, rozpisana na wiele wersji w Brunonie. Epoce genialnej, tłumacząca kształt wstępu do wydania w „Bibliotece Narodowej” i może tylko w serii „A to Polska właśnie” potraktowana jak inne wydarzenia i zgodna z popularnonaukową konwencją serii, w której życiorysy bohaterów zostają zunifikowane.

Mimo rady Kendalla dumni ze swoich odkryć biografowie nieraz wydłużają i nasycają szczegółami pewne partie opowieści, gdy zbiorą na jakiś temat wiele informacji. Wtedy dane wydarzenie zostaje dowartościowane, a następnie nawet głęboko utrwalone w tradycji niejako przez przypadek. W wypadku Schulza nieźle opisane zostają relacje z osobami, do których listy ocalały mimo niszczycielskiego wpływu Historii: Deborą Vogel, Józefiną Szelińską, Romaną Halpern, Anną Płockier. Nie podważam ich roli w życiu Schulza. Co natomiast z tymi, o których nic nie wiemy lub wiemy bardzo mało, jak tajemnicza Stefania Dretler-Flin? Słowem nie wspomina o niej Kaszuba-Dębska, która cytuje za to obszerne narzekania Schulza na niesforność drohobyckiej młodzieży szkolnej ${ }^{33}$.

Biograf może też skracać swoją opowieść na jakiś temat, jeśli uważa go za nudny dla czytelnika lub nieistotny, albo nawet omijać w potencjalnej narracji znane sobie wydarzenia czy całe ich sekwencje. W takim wypadku wie, że coś spotkało bohatera, ale celowo skrywa to przed czytelnikiem - zapewne w imię tej samej prawdy, dla której inne wydarzenie

30 S. Chwedorczuk, Kowalska. Ta od Dąbrowskiej, Warszawa 2020.

31 A. Domosławski, Kapuściński non-fiction, Warszawa 2010.

32 Zob. A. Synoradzka-Demadre, Jerzy Andrzejewski, s. 13.

33 A. Kaszuba-Dębska, Bruno, s. 135-137. 
skazane na banicję

przymus milczenia opisuje ze szczegółami. Jego wybory mogą być jednostkowe, ale konkretne tematy bywają pomijane lub tylko wzmiankowane ze względów kulturowych czy stricte ideologicznych, analogicznie do reprezentowania i nadreprezentowania innych tematów. Rosiek - kreśląc projekt kalendarza życia Schulza - sięgnął po metaforę wygnania: „Wybór bowiem jest prawem (często stosowanym opacznie) i przywilejem (często nadużywanym) biografa, który tworzy dyskurs wedle własnej zasady, włączając w jego ramy zaledwie część znanych mu zdarzeń, inne skazując na banicję: marginalizację lub zapomnienie"34. Takim zaś komentarzem opatrzył działania Ficowskiego Marcin Romanowski: „Rozważając problem (nie)obecności sfery erotycznej w biografii, powinniśmy oczywiście brać pod uwagę kontekst kulturowy, w jakim narracja biograficzna powstaje, a także w jakim powstają świadectwa, na których biograf opiera swą pracę. Ów kontekst kulturowy kształtuje ramy tego, co na temat seksualności bohatera można powiedzieć. To, co z naszej perspektywy, z perspektywy drugiej dekady XXI wieku, wydaje się nadmiernie powściągliwe, w czasach pisania Regionów (lata sześćdziesiąte XX stulecia) było po prostu kwestią decorum"35. Gdy czytam Regiony wielkiej herezji, nie mam poczucia, że Ficowski pomijał masochizm Schulza. Po prostu dziś wiemy, że nie pisał o wszystkim, o czym mówili mu świadkowie. I oczywiście, dla Ficowskiego masochizm Schulza był raczej strategią artystyczną niż faktem biograficznym. Ale Schulz masochista nie podzielił pośmiertnego losu pisarzy homoseksualistów, których seksualność przez dekady pozostawała przemilczana.

Przyczyną niedoreprezentowywania lub pomijania pewnych wydarzeń w biografii jest też niedostateczna ilość materiału lub niewiedza na jakiś temat. $\mathrm{W}$ takim wypadku biograf może tylko o czymś napomknąć lub postawić hipotezę, świadomie przemilczeć temat, by nie wprowadzić czytelnika w błąd, lub w ogóle nie mieć wiedzy o jakimś wydarzeniu. W wypadku Schulza - jak to przejmująco określił Ficowski - archiwum jest skromne i nastręcza biografom wielu trudności: „Wojna, zmiana granic kraju, śmierć większości najbliższych przyjaciół Schulza, zagłada jego obfitej korespondencji, zaginięcie wszystkich jego autografów i rękopisów - wszystko to sprawiło, że trzeba było działać prawie po omacku, często metodami nieomal detektywistycznymi, a niekiedy - archeologicznymi. Tak dokładnie zaprzepaścił się czas jego biografii i jej bliscy świadkowie" ${ }^{36}$. I tak żaden z dotychczasowych biografów nie wiedział o faktycznym debiucie Schulza, którym było opowiadanie 
Undula, opublikowane pod pseudonimem Marceli Weron w czasopiśmie nafciarzy „Świt”37. Kaszubie-Dębskiej udało się wspomnieć o tym fakcie we wstępie, gdy reszta książki była już gotowa ${ }^{38}$. Dopiero od czasu digitalizacji metryk urodzenia widomo również, że rodzice Schulza nie mieli tylko trojga dzieci, które dożyły wieku dorosłego. Niejednokrotnie biografowie są zmuszeni sygnalizować zdarzenia, o których niewiele wiadomo, dotyczy to również biografów Schulza. Mimo że przez pierwsze cztery lata edukacji uczył się on w męskiej szkole ludowej, zarówno Ficowski, jak i Jarzębski piszą tylko o jego okresie gimnazjalnym. Budzyński cytuje ucznia, który wspominał, że chodził do tej samej szkoły co Schulz. Dopiero Kaszuba-Dębska porusza temat szkoły ludowej, ale nie dysponuje materiałami, by podawać jakieś szczegóły 39 .

„Weźmy za przykład historię całego życia, tak często spotykaną w literaturze XIX wieku. Na fabułę składają się narodziny bohatera, jego dzieciństwo, dojrzewanie, służba wojskowa, pierwsza miłość, ambicje społeczne, stopniowe niedołężnienie oraz śmierć. Można określić liczbę stron przeznaczoną na każdy z tych etapów. To proste ćwiczenie często pokazuje, że niektórym z nich poświęca się więcej uwagi niż innym. Na przykład dzieciństwo jest zazwyczaj szybko streszczane, podczas gdy o «pierwszej miłości» pisze się o wiele bardziej szczegółowo" - tak Mieke Bal pisze o relacjach czasowych między fazami życia bohatera dziewiętnastowiecznej powieści ${ }^{40}$. Często podobny układ możemy zaobserwować w wypadku biografii pisarzy. Dzieciństwo podlega bowiem wszystkim znanym z powieści mechanizmom skracania i pomijania. Przyznaje to Anna Arno: „Dla biografa pierwsze dwadzieścia lat życia bohatera to właściwie jeden rozdział, dużo tu gdybania, historia miasta, z którego pochodził, dzieje rodziny. Ale już dwadzieścia lat między czterdziestką a sześćdziesiątką albo między sześćdziesiątką a osiemdziesiątką, to jest potężna praca"41.

Podejście do tematu dzieciństwa w biografistyce można by prześledzić w czasie - tak jak na ogólnym poziomie kultury Zachodu zrobił to

37 Zob. Ł. Chomycz, Wokół wystawy w Borysławiu. O dwóch debiutach Brunona Schulza, przeł. A. Pomorski, „Schulz/Forum” 14, 2019, s. 13-32.

38 A. Kaszuba-Dębska, Bruno, s. 12-13.

39 Ibidem, s. 133-137. Por. K. Warska, 1898-1902, https://schulzforum.pl/pl/kalendarz/1898-1902 (dostęp: 12.01.2020).

40 M. Bal, Narratologia. Wprowadzenie do teorii narracji, przeł. E. Kraskowska, E. Rajewska, Kraków 2012, s. 102.

41 Biografia. O atrakcyjności gatunku i jego pułapkach, w rozmowie uczestniczyli: A. Arno, A. Czabanowska-Wróbel, G. Kubica-Heller, M. Szumna, M. Urbanowski, T. Walas i M. Wyka, moderowała A. Pekaniec, "Dekada Literacka” 2018, nr 2/3 (36/37), s. 39. 
niegodne biografii

sześć akapitów
Philippe Ariès. Bez wątpienia kulturowe klisze odbijają się w biografistyce. Do pewnego czasu dzieciństwo wydaje się użyteczne w biografii pisarza tylko wtedy, gdy biograf odkryje w nim jakieś wydarzenie formacyjne. Jeśli rutyna życia dorosłego pisarza mało kogo interesuje, cóż dopiero powiedzieć o codzienności dziecka? Kto zabawę w chowanego $\mathrm{z}$ przyjaciółmi z dzieciństwa potraktuje równie poważnie jak wymianę korespondencji z innym wybitnym literatem? Z przeświadczenia o niewielkiej wadze wydarzeń z pierwszych kilkunastu lat życia wynika też brak materiałów do pisania biografii. Niewiele się zachowuje z tego okresu i niewiele można $\mathrm{z}$ niego rekonstruować.

Natomiast analizując biografie synchronicznie, można zaobserwować różnice w zależności od przyjętej przez autora konwencji biograficznej. Dzieciństwo jest raczej pobieżnie omawiane w monografiach typu życie i twórczość, takich jak wstępy do edycji w „Bibliotece Narodowej”. Michał Głowiński we wstępie do Wierszy wybranych Tuwima pomija jego dzieciństwo ${ }^{42}$. Andrzej Zawada poświęca dzieciństwu Iwaszkiewicza sześć akapitów - niecałe trzy strony na 21 stron całego segmentu biograficznego ${ }^{43}$. Trzy akapity o dzieciństwie Leśmiana znajdziemy w opracowaniu autorstwa Jacka Trznadla ${ }^{44}$. Sześć akapitów na dwóch stronach w stosunku do 42 stron całości, traktowanych łącznie życia i twórczości, poświęca Ewa Wiegandtowa dzieciństwu Wittlina ${ }^{45}$. Podobnie sześć akapitów - dwie strony w stosunku do 41 stron opowieści o całym życiu Zegadłowicza - zajmuje Mirosławowi Wójcikowi opowiedzenie jego dzieciństwa ${ }^{46}$. Tych sześć akapitów wydaje się więc średnią objętością opowieści o dzieciństwie we wstępach do edycji w „Bibliotece Narodowej”. Ten wynik przekraczają noty o pisarzach, których ojcowie byli pisarzami. Włodzimierz Bolecki we wstępie do Pożegnania jesieni rozpisał dzieciństwo Witkacego na czternaście akapitów - prawie sześć stron, z których stronę zajmuje opowieść o chrzcie - na 31 stron „Informacji biograficznych”47. Natomiast Jan Błoński dzieciństwu Witkacego poświęcił jedenaście akapitów zajmujących cztery i pół strony na 26 stron całego życiorysu ${ }^{\mathbf{4 8}}$. Włodzimierz Wójcik we wstępie do Granicy podważyłby tezę o marginalizacji dzieciństwa we

42 M. Głowiński, Wstęp, w: J. Tuwim, Wiersze wybrane, oprac. M. Głowiński, wyd. 4 rozszerzone, Wrocław 1986.

43 A. Zawada, Wstęp, w: J. Iwaszkiewicz, Opowiadania wybrane, oprac. A. Zawada, Wrocław 2001, s. V- XXI.

44 J. Trznadel, Wstęp, w: B. Leśmian, Poezje wybrane, oprac. J. Trznadel, wyd. 1 elektroniczne, na podstawie wyd. 3 rozszerzonego (1991), Wrocław 2019, epub.

45 E. Wiegandtowa, Wstęp, w: J. Wittlin, Sól ziemi, oprac. E. Wiegandtowa, Wrocław 1991, s. VI-XLII.

46 M. Wójcik, Wstęp, w: E. Zegadłowicz, Zmory. Kronika z zamierzchłej przeszłości, oprac. M. Wójcik, Wrocław 2006, s. VII-XLVIII.

47 W. Bolecki, Wstęp, w: S.I. Witkiewicz, Pożegnanie jesieni, wstęp i oprac. W. Bolecki, Wrocław 2017, s. V-XI.

48 J. Błoński, Wstęp, w: S.I. Witkiewicz, Wybór dramatów, wyboru dokonał i wstępem poprzedził J. Błoński, tekst i przypisy oprac. M. Kwaśny, wyd. 2 poprawione, Wrocław 1983, s. V-XXIX. 
wstępach do wydań w „Bibliotece Narodowej” z 11 akapitami o pierwszych kilkunastu latach życia Nałkowskiej na 18 akapitów całej opowieści, ale tytułując tę część swojego tekstu „Środowisko rodzinne”, właściwie potwierdza regułę. Przy czym w części poświęconej literaturze nie brakuje we wstępie Włodzimierza Wójcika młodzieńczych lektur Nałkowskiej oraz jej debiutu w wieku lat $14^{49}$. We wstępie Wiegandtowej do Romansu Teresy Hennert zaś poznajemy Nałkowską nastoletnią, autorkę i bohaterkę swoich Dzienników, pensjonarkę i początkującą pisarkę. Temat tej opowieści, na którą składa się 25 akapitów, trudno nazwać dzieciństwem; mowa jest raczej o wczesnej dojrzałości i jej rodzinno-społecznych okolicznościach ${ }^{50}$.

Inny standard wyznaczają dwudziestopierwszowieczne biografie totalne. Na przykład Radosław Romaniuk w biografii Iwaszkiewicza szczegółowo analizuje relacje rodzinne, klimat dzieciństwa, zetknięcia z kulturą i sztuką, edukację, rozrywki, wychowanie i socjalizację, podróże, śmierć ojca, przeprowadzki do Warszawy, Elizawetgradu i Kijowa ze wszystkimi ich konsekwencjami, pierwsze przebłyski talentu literackiego, udzielanie korepetycji niewiele młodszym uczniom, relacje z rówieśnikami, rodzący się (homo)erotyzm i dramaty egzystencjalne ${ }^{51}$. Podobnie Suchanow, która jeszcze szerzej i jeszcze szczegółowiej zarysowuje tło dorastania Gombrowicza ${ }^{52}$.

Jednocześnie dzieciństwo można uznać za najważniejszy okres w życiu człowieka. Twierdzi tak od swego zarania psychoanaliza. Zacytujmy na przykład słowa jej ojca, Zygmunta Freuda, z niedokończonego Zarysu psychoanalizy: „doświadczenie psychoanalityczne przekonało nas o całkowitej słuszności często wypowiadanego stwierdzenia - psychologicznie rzecz biorąc - dziecko jest ojcem człowieka dorosłego, a przeżycia z pierwszych lat mają niedościgłe znaczenie dla całego jego późniejszego życia"53. Tym tropem idzie Suchanow, analizując relacje Gombrowicza z matką. Dziś dzieciństwo jest istotne także dla innych niż psychoanalityczne odłamów psychologii rozwojowej, która cieszy się coraz większym zainteresowaniem szerokiego kręgu osób, zwłaszcza rodziców. Wiemy to na pewno: nasze funkcjonowanie jako dorosłych zależy od doświadczeń z dzieciństwa.

Ze względów etycznych dowartościowują etap dzieciństwa children studies. Karolina Szymborska w „Tekstach Drugich” relacjonuje ambicje

49 W. Wójcik, Wstęp, w: Z. Nałkowska, Granica, oprac. W. Wójcik, Wrocław 1971, s. III- XIV.

50 E. Wiegandt, Wstęp, w: Z. Nałkowska, Romans Teresy Hennert, Wrocław 2001, s. V-XIV.

51 R. Romaniuk, Inne życie. Biografia Jarosława Iwaszkiewicza, t. 1, Warszawa 2012, rozdz. "Domy i ludzie”, „Wyspa Tymoszówka”, „Stracone pokolenie”, ,Strona Byszew”.

52 K. Suchanow, Gombrowicz, rozdz. "Małoszyce”, "Służewska 3”.

53 Z. Freud, Zarys psychoanalizy, w: idem, Poza zasadą przyjemności, przeł. J. Prokopiuk, Warszawa 1975 , s. 196. 
dzieciństwo to...

tej zintegrowanej, interdyscyplinarnej dziedziny badań: widzi w nim kolejny z ruchów upominający się o upodmiotawianie wykluczonego. Badacze spod znaku children studies rozpoznają, że nasza kultura jest adultocentryczna i najwyższy czas zwrócić uwagę ku dzieciom i dzieciństwu ${ }^{54}$. I nawet jeśli nie jest to dziedzina bezpośrednio oddziałująca na biografistykę, to wyrasta z ponowoczesnego sposobu pojmowania człowieka, którego głośne echo słychać na polu biografistyki od kilkunastu lat.

Dzieciństwo to konstrukt, na który składają się podobnie jak w późniejszych fazach życia: płeć, pochodzenie etniczne, klasa społeczna. To także okres socjalizacji, gdy interioryzujemy obowiązujące wokół nas zasady. W perspektywie kulturowej zobaczymy w nim wiele czynników kształtujących obraz świata, który znajduje odzwierciedlenie w dziele literackim. Ale uznać doświadczenie dziecka za pełnoprawne - to chyba zobaczyć w dzieciństwie doświadczenie. W tym miejscu trudno nie odwołać się do powszechnego odczucia: dzieciństwo jest dla nas ważne. To ciągłe zdziwienia, niewinność i nieskrępowanie. Silne emocje, na których skupia się na przykład Chwedorczuk, co zapewne wynika w dużej mierze z bazowania na dzienniku Kowalskiej55. Dzieciństwo to relacje z rodziną, rówieśnikami, autorytetami, czasem też oprawcami. To też szkoła z jej programem nauczania, przestrzenią, procedurami. Na przykład Kirchner wyraźnie rysuje portret młodej Nałkowskiej jako ponadprzeciętnie zdolnej buntowniczki ${ }^{56}$. To pierwsze lektury i spotkania z kulturą. Miejsca, do których z sentymentem wracamy i które mogą nam się potem śnić przez całe życie. Tym tropem idzie Suchanow, wcielając w życie teorię Rybickiej o (auto)bio/geo/grafii 57 .

Ze wszystkich tych powodów skracanie czy pomijanie dzieciństwa w biografii wydaje się zubażające dla czytelniczego oglądu bohatera oraz godzące w ową - choćby podejrzaną - prawdę wewnętrzną i historyczną.

W wypadku biografii Schulza na dzieciństwo każe nam patrzeć na przykład, rzekomo śniony w wieku siedmiu lat, sen o kastracji, relacjonowany Stefanowi Szumanowi w liście z 24 lipca 1932 roku8. Wielu literaturoznawców interpretowało sztukę Schulza przez pryzmat tego snu,

54 K. Szymborska, Children studies jako perspektywa metodologiczna. Współczesne tendencje w badaniach nad dzieckiem, "Teksty Drugie” 2016, nr 1, s. 189-205.

55 S. Chwedorczuk, Kowalska, rozdz. " "Głód czułości»".

56 H. Kirchner, Nałkowska albo życie pisane, rozdz. „Kwiat rodu”.

57 Zob. E. Rybicka, Auto/bio/geo/grafie, „Białostockie Studia Literaturoznawcze” 2003, nr 4, s. 7-23.

58 B. Schulz, List do Stefana Szumana z 24 lipca 1932, w: idem, Dzieła zebrane, t. 5: Księga listów, zebrał i przygotował do druku J. Ficowski, uzupełnił S. Danecki, Gdańsk 2016, s. 36. 
który należy uznać za istotny niezależnie od tego, czy rzeczywiście się Schulzowi przyśnił, czy został wymyślony na potrzeby autoidentyfikacji ${ }^{59}$. Poza tym, co jest truizmem, Schulz swoje dzieciństwo opisał prozą, i to tak sugestywnie, że właściwie stało się ono synonimem dzieciństwa jako tematu literackiego. Potwierdzają to tematy lekcji języka polskiego i tematy maturalne, które są jednymi z łatwo dostrzegalnych wskaźników kanoniczności. Autobiografizm opowiadań Schulza narzuca się do tego stopnia, że w interpretacji trudno nie potknąć się o biografię pisarza. Nie znaczy to oczywiście, by naiwnie rozpatrywać opowiadania jako źródło wiedzy biograficznej, co zdarza się Kaszubie-Dębskiej. Jednak pozostają w mocy słowa Jarzębskiego ze wstępu do Sklepów cynamonowych, wydanych w ramach Dzieł zebranych: „To dość oczywiste, że Schulz utożsamia się ze swoim bohaterem, Józefem. Ale to utożsamienie ma szczególny charakter, bo w roli bohatera Schulz niejako projektuje siebie $\mathrm{w}$ różnych chwilach życia: jest dzieckiem, młodzieńcem, a nawet starcem stojącym nad grobem. Dokonuje więc przeglądu swego życia, oglądając je z różnych perspektyw i próbując mu nadać rozmaite sensy" 60 .

Dlatego Ficowski sporo pisał o dzieciństwie w Regionach wielkiej herezji, które - rozpatrywane w swojej ostatniej wersji z Regionów wielkiej herezji i okolic - obejmują jedenaście stron tekstu z ilustracjami na temat biografii i kolejne dziesięć o twórczości - powtórzonym dzieciństwie ${ }^{61}$. Mniej więcej w tym czasie, gdy Ficowski po raz pierwszy wydał Regiony (1967), ukazały się inne monografie typu „życie i twórczość": Zygmunt Krasiński - debiut i dojrzałość (1962) Marii Janion; Orzeszkowa (1965) Marii Żmigrodzkiej; Józef Ignacy Kraszewski (1967) Wincentego Danka czy Teofil Lenartowicz i jego poezje (1970) Jana Nowakowskiego ${ }^{62}$. Ficowski zaczyna chronologicznie, od narodzin Schulza. Opowiada o ówczesnym Drohobyczu, rodzinie, żydostwie, relacjach z rodzicami i rówieśnikami, szkole, pierwszych przejawach talentu artystycznego i literackiego,

59 Zob. np. M.P. Markowski, Powszechna rozwiq̨złość. Schulz, egzystencja, literatura, Kraków 2012, s. 79; W. Owczarski, Miejsca wspólne, miejsca własne. O wyobraźni Leśmiana, Schulza i Kantora, Gdańsk 2006; T. Olchanowski, Jungowska interpretacja mitu ojca w prozie Brunona Schulza, Białystok 2001, s. 73-76; M. Zaleski, Masochista na Cyterze, „Teksty Drugie” 2005, nr 3, s. 184-203; S. Rosiek, Odcięcie. Siedem fragmentów, "Schulz/Forum” 7, 2016, s. 25-64; F. Szałasek, Erros Schulza, "Schulz/Forum" 7, 2016, s. 75-90.

60 J. Jarzębski, Sklepy bławatne i sklepy cynamonowe, w: B. Schulz, Dzieła zebrane, t. 2: Sklepy cynamonowe, wstęp i oprac. J. Jarzębski, dodatek krytyczny S. Rosiek, oprac. językowe M. Ogonowska, Gdańsk 2019, s. 23.

61 J. Ficowski, Regiony wielkiej herezji i okolice, s. 17-28, 29-38.

62 M. Janion, Zygmunt Krasiński - debiut i dojrzałość, Warszawa 1962; M. Żmigrodzka, Orzeszkowa. Młodość pozytywizmu, Warszawa 1965; W. Danek, Józef Ignacy Kraszewski. Żywot i dzieła, Kraków 1967; J. Nowakowski, Teofil Lenartowicz i jego poezje, Kraków 1970. 


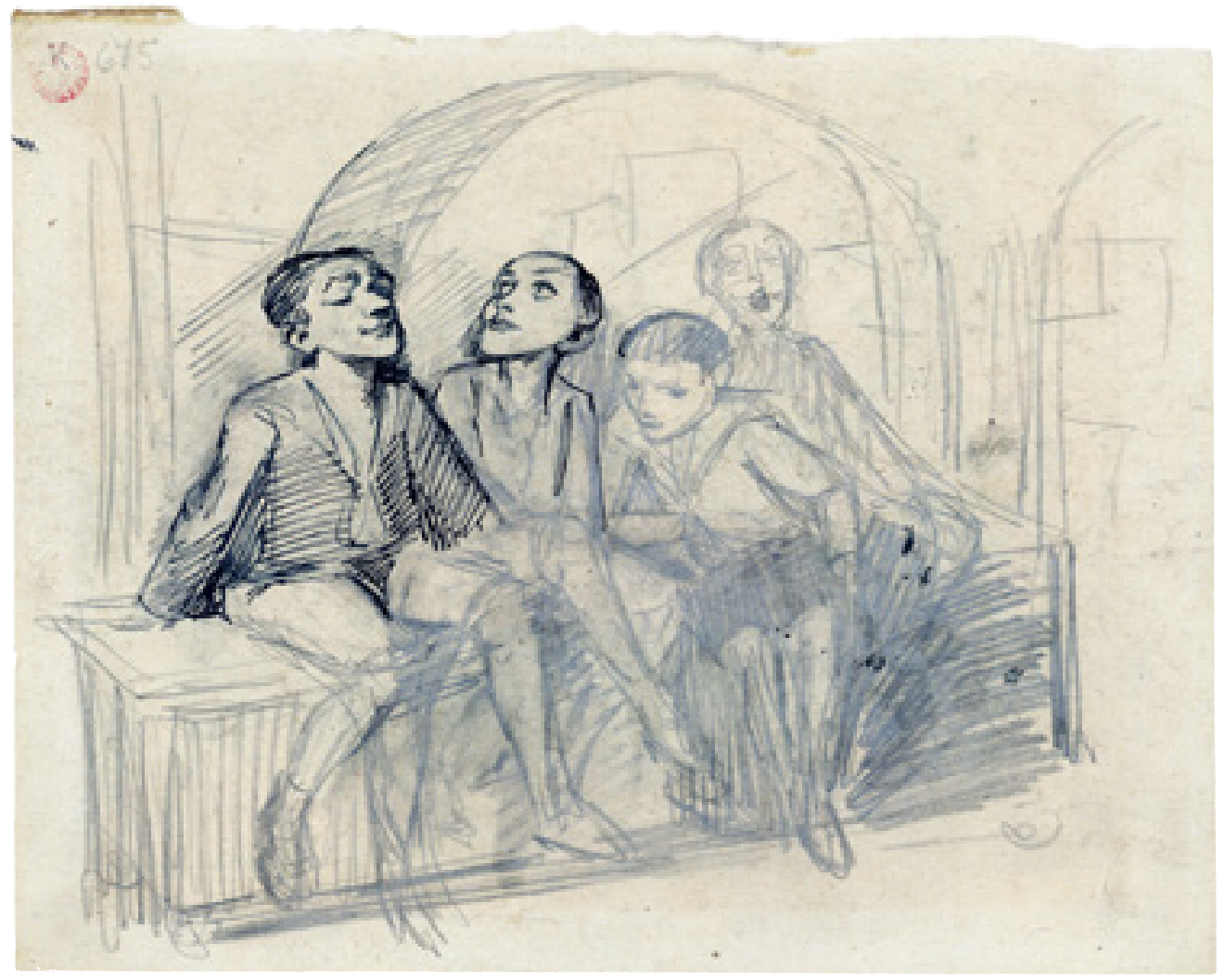

Bruno Schulz, Chłopcy w sieni przy rynku III, ok. 1936, ołówek, tusz, 16,5×20,3cm, Muzeum Literatury w Warszawie

Bruno Schulz, Chłopcy w sieni przy rynku I, ok. 1935, ołówek, 20,5×16,5 cm, Muzeum Literatury w Warszawie

Bruno Schulz, Chłopcy w sieni przy rynku II - ilustracja do opowiadania Wiosna zamieszczona w tomie Sanatorium pod Klepsydra, przed 1937, tusz, rysunek zaginiony 

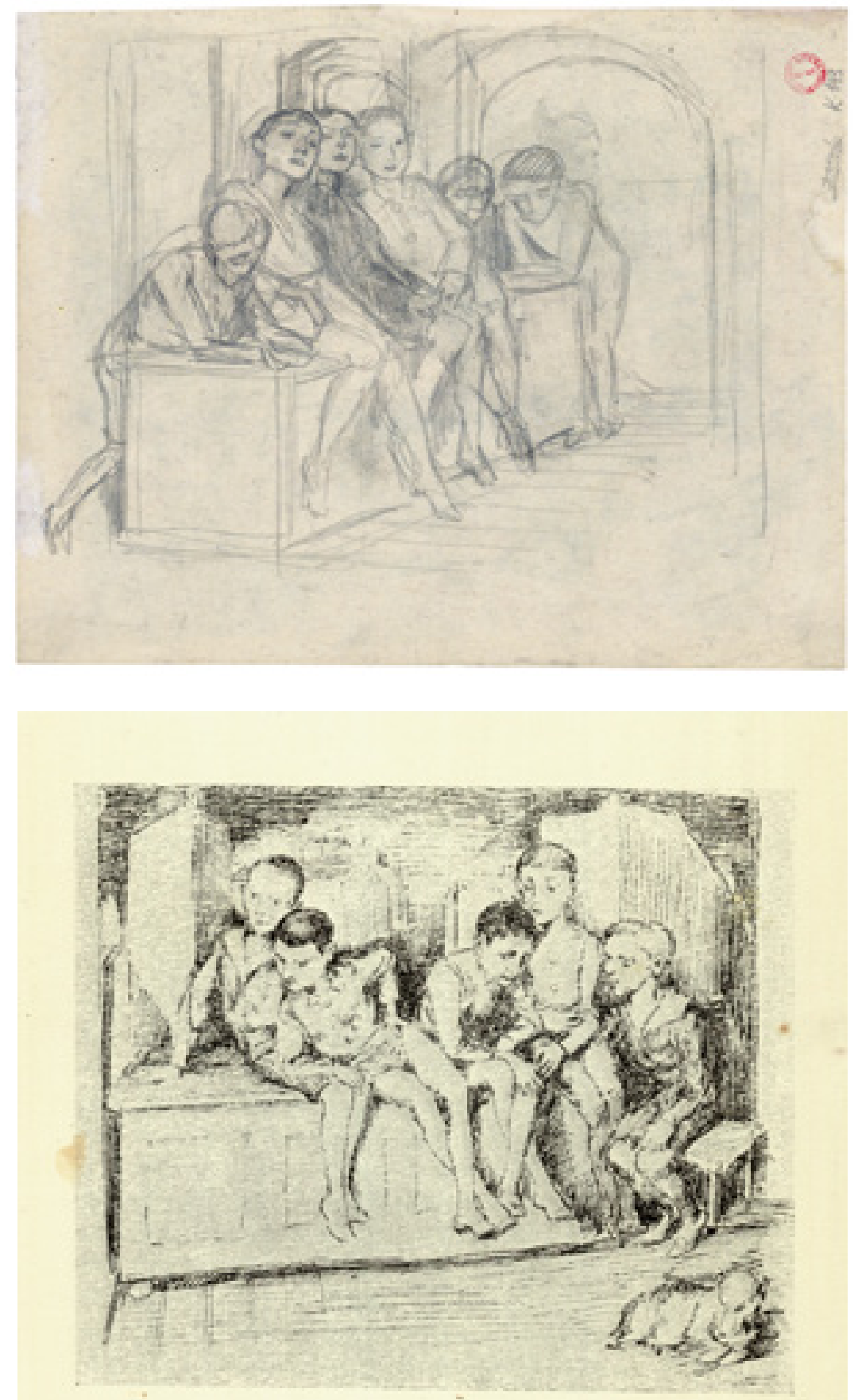


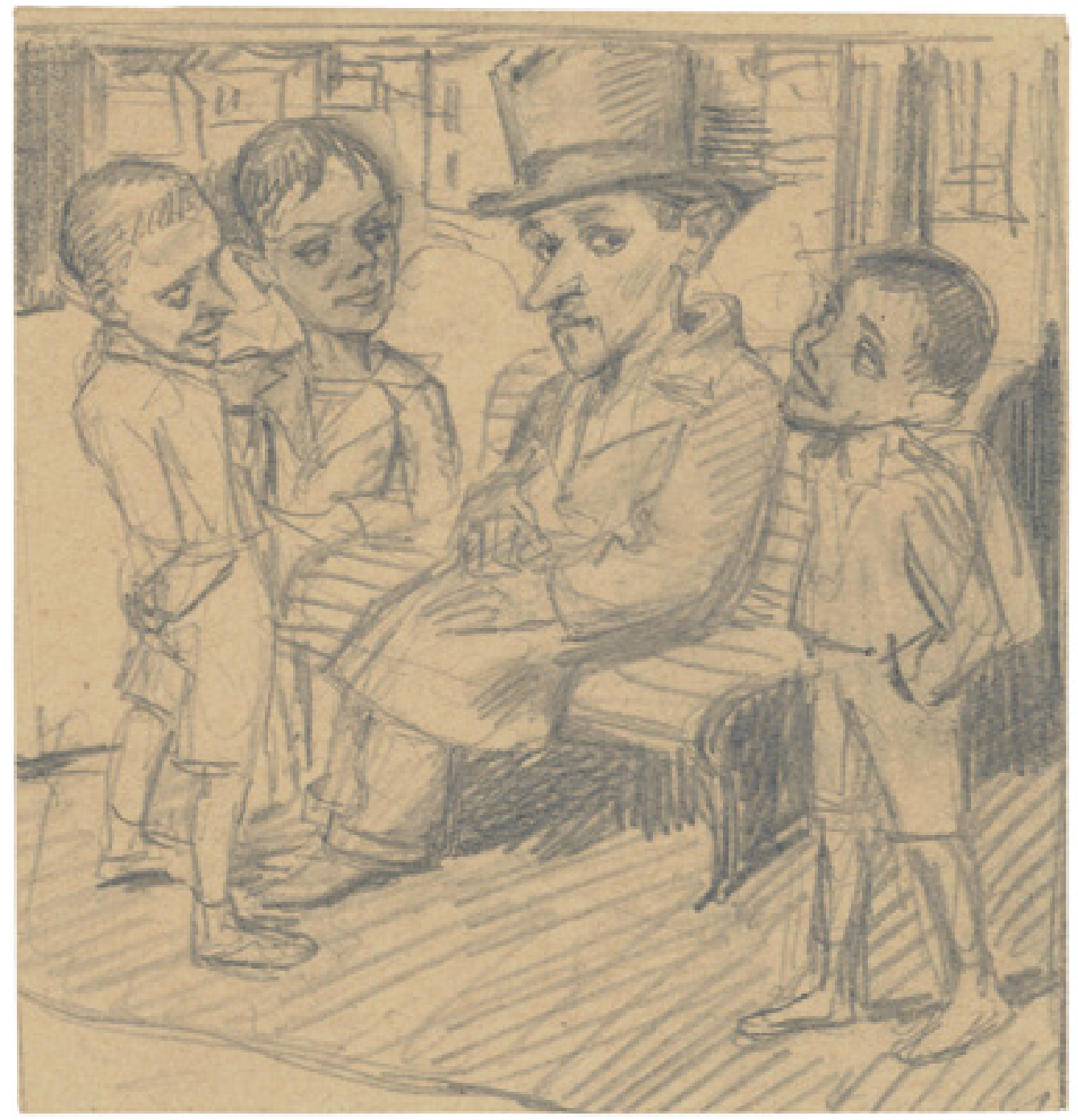

Bruno Schulz, Emeryt z chłopcami na ławce,

przed 1937, ołówek, 11,2×10,6 cm, Muzeum

Literatury w Warszawie 
fizjonomii i cechach psychicznych. Ten etap życia swojego bohatera opowiada aż po studia i I wojnę światową. W swoim oglądzie dzieciństwa Ficowski chce podążać za Schulzem: „Najaktywniejszy duchowo stosunek do otaczającej rzeczywistości daje dzieciństwo: każdemu odbiorowi wrażeń, każdemu doznaniu towarzyszy akt kreatorski wyobraźni, na każdym kroku rodzą się mity etiologiczne. Jest to powtarzający się na wstępie każdej indywidualnej biografii prapoczątek, stworzenie świata. Rzeczywistość, zaznawana po raz pierwszy, nie usystematyzowana doświadczeniem, nie obciążona żadną wiedzą o jej prawidłach i strukturze, podporządkowuje się nowym asocjacjom, przybiera proponowane jej kształty, ożywa zapłodniona dynamizującym widzeniem. Tam właśnie, w owej mitotwórczej sferze, jest źródło, i meta dzieła Brunona Schulza i jego programu artystycznego"63.

Wiesław Budzyński w Schulzu pod kluczem, przeskakując z tematu na temat, o dzieciństwie wspomina tylko przy okazji. Schulz jest u niego od razu dorosły, by nie powiedzieć - od razu martwy. Na ten brak dzieciństwa jest oczywiście proste wytłumaczenie: dzieciństwo było wtedy tematem zagospodarowanym przez Ficowskiego. Do tego niespecjalnie znali je informatorzy Budzyńskiego, z których opowieści budował on swoją narrację.

We wstępie do wydania w „Bibliotece Narodowej”, przygotowanym przez Jarzębskiego, dzieciństwo Schulza jest jako faza życia proporcjonalne do innych faz. Obejmuje pięć akapitów (dwie strony), w stosunku do trzynastu i pół strony całej części biograficznej. Za pierwsze lata dzieciństwa starcza opowieść o ówczesnym Drohobyczu. Potem następuje etap szkolny: Schulz ujawnia talent, cierpi wyobcowanie, zdradza predylekcję do masochizmu. Po czasie względnie spokojnym następuje trudna sytuacja rodzinna. Później Schulz idzie na studia ${ }^{64}$. W Schulzu z „A to Polska właśnie” jego dzieciństwo wygląda właściwie podobnie, choć cała książka jest znaczenie obszerniejsza niż wstęp do Opowiadań. Główną informacją są dobre wyniki w nauce ${ }^{65}$.

Kaszuba-Dębska w Kobietach Schulza portretuje matkę Schulza, a przy okazji pokrótce wspomina o jego dzieciństwie ${ }^{66}$. W Epoce genialnej stara się odtworzyć dzieciństwo, lecz wyraźnie brak jej materiałów. W szkole ludowej Schulza omawianej przez tę autorkę panuje bieda i wyprawia się harce. Potem Schulz pisze egzaminy, dostaje psa (choć to informacja raczej z biografii literackiej). Idzie do gimnazjum - to dla niego wspaniały

\footnotetext{
63 J. Ficowski, Regiony wielkiej herezji i okolice, s. 29.

64 J. Jarzębski, Wstęp, s. IX-X.

65 Idem, Schulz, s. 29-31.

66 A. Kaszuba-Dębska, Kobiety Schulza, s. 313-314.
} 
dzieciństwo jako wyzwanie druga motywacja biografa okres: ma świetne wyniki w nauce, dobre relacje z kolegami i może rozwijać swoją wielką pasję - rysowanie 67 .

Od pierwszego wydania Regionów wielkiej herezji minęły już 54 lata. Od tamtej pory nie zaszła rewolucja w oglądzie biograficznego dzieciństwa Schulza. W perspektywie wagi tego tematu pozostaje ono nadal - jak ująłby to Rosiek - wyzwaniem dla schulzologii68. Próbowała zmienić ten stan tylko Kaszuba-Dębska, raczej bez powodzenia. Oczywiście otwarte pozostaje pytanie, czy sukces jest w ogóle możliwy do osiągniecia, choćby w perspektywie wszystkiego, o czym pisałam powyżej. Kolejne podejście do biografii całościowej autora Sklepów zdarzy się pewnie nieprędko. Jednak powstaje rządzący się wyłącznie porządkiem czasu $\mathrm{Ka}$ lendarz życia, twórczości i recepcji Brunona Schulza, który „ma ustalać tekst życia Schulza"69. W dalszej kolejności powinien on posłużyć biografom jako punkt wyjścia ich badań.

Tu warto wspomnieć, niby już poniewczasie, o drugiej możliwej motywacji biografa Schulza. Jest to chęć opowiedzenia czegoś istotnego o nas wszystkich: o sobie, o czytelniku, nie tylko o minionych, lecz także obecnych czasach. Może w biografii da się odsłaniać tę - również częściową - prawdę, gdyż - jak pisał Michał Paweł Markowski - jest ona „gatunkiem moralnym, nie dlatego, że przestrzega moralnych reguł, lecz dlatego, że pozwala nam lepiej zrozumieć innych ludzi. A przez to samych siebie"70. Zapewne dzięki tym możliwościom biografie, w tym biografie Brunona Schulza, nie są czytane wyłącznie przez specjalistów, ale też i to bardzo chętnie - przez postronnych poszukiwaczy migotliwych prawd egzystencji. Znajdując dzieciństwo Schulza, może i przed nimi uda się nam roztoczyć nową perspektywę. By ktoś kiedyś powtórzył: „Schulz mój bliźni”71.

67 Eadem, Bruno, s. 150.

68 Zob. S. Rosiek, Biografia Schulza jako wyzwanie (rzucone historii), s. 71-81.

69 Ibidem, s. 74.

70 M.P. Markowski, Cień biografa, https://www.tygodnikpowszechny.pl/cien-biografa-145068 (dostęp: 24.01.2021).

71 Zob. jo, Schulz nasz bliźni, „Schulz/Forum” 12, 2018, s. 4. 